\title{
Is the fossil record of complex animal behaviour a stratigraphical analogue for the Anthropocene?
}

\author{
M. WILLIAMS ${ }^{1}$, J.A. ZALASIEWICZ ${ }^{1}$, C.N. WATERS ${ }^{2}$ \& E. LANDING ${ }^{3}$ \\ ${ }^{1}$ Department of Geology, University of Leicester, Leicester, Leicester LE1 7RH, UK \\ (e-mail:mri@le.ac.uk) \\ ${ }^{2}$ British Geological Survey, Keyworth, Nottingham, NG12 5GG, UK \\ ${ }^{3}$ New York State Museum, 222 Madison Avenue, Albany, NY 12230, USA
}

Abbreviated title: Precambrian-Cambrian boundary: analogue for the Anthropocene?

\begin{abstract}
The base of the Cambrian System is recognised by a characteristic (marine) trace fossil suite assigned to the Treptichnus pedum Biozone that signals increasing complexity of animal behaviour, and demarcates the Cambrian from the (older) Ediacaran System (Proterozoic Eonathem). Ichnotaxa of the T. pedum Biozone are not the earliest trace fossils, and are preceded in the latest Proterozoic by a progressive increase in the diversity of trace-producing organisms and the communities they comprised, the structural and behavioural complexity of the trace fossils, and even the depth of burrowing in sediments. Parallels can be drawn with the increasing complexity of subsurface structures associated with human cities, which also reflect evolution of an increasingly complex community. Prior to the $19^{\text {th }}$ century these structures were limited and simple, but beginning with the development of London in the mid- $19^{\text {th }}$ century as the world's first megacity, subsurface structures have become increasingly complex, reflecting the technologydriven behaviour of $20^{\text {th }}$ and $21^{\text {st }}$ century humans.
\end{abstract}


Keywords: Cambrian, Anthropocene, trace fossils, animal behaviour

This paper examines the similarity between the evolution of complex animal behaviour whose trace fossil record is used to recognise the base of the Cambrian System $541 \pm 0.63$ million years ago (Peng et al. 2012), and the complex animal behaviour of the $19^{\text {th }}$ to $21^{\text {st }}$ centuries that is manifested in the growth of megacities (those urban areas with populations greater than 10 million inhabitants). This physical record of human activity could be used in defining, for instance, the base of a formal Anthropocene Epoch/Series.

\section{Definition of the base of the Cambrian}

The Cambrian is the earliest period/lowermost system of the Phanerozoic Eon/Eonathem. The base of the system and of its lowermost Terreneuvian Series and very lowest Fortunian Stage (Landing et al. 2007) is recognised by the lowest occurrence of a globally widespread trace fossil suite referred to the Treptichnus pedum Biozone at its Global Boundary Stratotype Section and Point (GSSP). This GSSP of the Cambrian is defined at a horizon located $2.4 \mathrm{~m}$ above the base of the lower Mystery Lake Member of the Chapel Island Formation on the Burin Peninsula of southeastern Newfoundland (Brasier et al. 1994; Landing 1994). The subhorizontal, branching burrow systems of T. pedum (Fig. 1, also referred to as Trichophycus pedum or Phycodes pedum in many reports) may represent the feeding and burrowing activity of priapulid worms or of an organism with similar locomotion (Vannier et al. 2010). 
Treptichnus pedum occurs in rock successions characterised by trace fossils that signal a progressive increase in animal behaviour more complex than that of the preceding (end-Proterozoic) Ediacaran System, and which, for example, include the arthropod scratch marks called Monomorphichnus (Jensen 2003). Although $T$. pedum has subsequently been recorded some 4 metres below the EdiacaranCambrian GSSP (see Gehling et al. 2001), the occurrence of this trace fossil nonetheless remains a useful approximate marker for the base of the Cambrian System (MacNaughton 2007). The ichnofauna of the T. pedum Biozone form part of the global fossil record of increasing complexity of marine ecosystems and organism behaviour that developed through the late Proterozoic and early Phanerozoic (Fig. 2), with the appearance of the soft-bodied Ediacaran biota some 580 million years ago (e.g., Yuan et al. 2011) and the earliest biomineralised fossils 549 million years ago (Wood et al. 2002; Zhuravlev et al. 2012). The earliest occurrence of T. pedum greatly preceded the global appearance of diverse mineralised (calcareous and phosphatic) small shelly fossils and, even later, the oldest trilobites (Fig. 2).

The Cambrian was defined with an underlying premise that it was the period during which Bilateria first evolved from simpler metazoan life. But without preservable hard-parts, evidence of such soft-bodied bilaterian organisms is restricted to preservation of their traces (ichnofossils), which are classified using the same binomial Linnaean system (i.e., Genus species, as Homo sapiens) as body fossils. Hence, definition of the system followed a route of a broad palaeontological concept of increasing biological (ecological and behavioural) complexity at the boundary, but that the boundary itself was recognised by the lowest appearance of a single representative ichnofauna. 
However, in detail this fossil record is more nuanced. Bilateria fossils such as Kimberella (Fedonkin \& Waggoner 1997); bilaterian, possibly arthropod, trace fossils (Martin et al. 2000); and trace fossils of bilaterian worms (Dornbos et al. 2005) occur coincident with Ediacaran assemblages in strata younger than 560 million years old. Treptichnid trace fossils that record simpler behavioural activity than that in Treptichnus pedum occur in strata younger than 550 million years (Jensen 2003). What specifically identifies the base of the Cambrian System, and of the Phanerozoic Eonathem, is the assemblage of complex behavioural patterns that are coincident with the widespread occurrence of $T$. pedum. The global changes in marine burrowing organism communities record the diversification, and perhaps origination, of many modern coelomate metazoans early in the Cambrian Evolutionary Radiation, as well as a major change in the world ocean, which included the recycling of nutrients back into the water column by burrowing animals (Landing \& Westrop 2004; Brasier et al. 2011)

It is important to remember that firstly, by recognising the base of a system through the first appearance of an ichnofauna at a specific locality, there is the possibility that globally, the onset of the T. pedum assemblage is diachronous. In some sections it may be that the first development of this trace fossil assemblage occurs later than at the GSSP. Even more importantly, it is important to understand that even with the best and most thorough study, the recorded range of any fossil invariably underestimates its actual range in every section (Marshall 1990)-thus even the range of Treptichnus pedum has proved to appear below the Cambrian GSSP at Fortune Head, eastern Newfoundland (Gehling et al. 2001). For this reason, Landing et al. (2007) qualified the base of the Cambrian, the Terreneuvian 
Series, and the Fortunian Stage as lying at the base of the T. pedum Biozone 'as known at the time of the ratification of the base of the Cambrian at Fortune Head.'

Secondly, there are limited numbers of sections through the relevant Precambrian-Cambrian boundary and even fewer that would have had the suitable environment for T. pedum to have developed or be preserved. Thirdly, though the accuracy of radiometric dating is rapidly advancing, at such temporally distant periods of time an error of \pm 0.63 million years for the Precambrian-Cambrian boundary provides a considerable range. The current system by which chronostratigraphy is defined (i.e., the definition of regional and global subdivisions of the rock record) allows for such uncertainties.

\section{Definition of the base of the Anthropocene}

If the Proterozoic-Phanerozoic boundary can be recognised by a change in animal behaviour, might not the base of the Anthropocene also be defined by a fundamental change in behaviour and more complex community structure, signalled by the global development of megacities with their extensive signature of trace fossils, including such physical records of human behaviour as roads, buildings, tunnels, canals, and other features? The route to the origins of megacities extends back over 2 million years, to the origins of human technology in the Palaeolithic (Fig. 2).

Megacities have antecedents in the early urban centres of the Fertile Crescent, Nile and Indus valleys, and in the large urban centres of ancient and historical times such as classical Rome in Europe, Alexandria in Africa, Baghdad in the Middle East, Tenochtitlan in the Americas, and Angkor in Asia. These cities have a considerable surface expression, but their classical remains, though including such structures as canals and brick-lined sewers, leave a more limited subsurface record, 
in effect mimicking the simplicity of the earliest late Proterozoic trace fossil assemblages (Jensen 2003). Compared to earlier cities, the megacities of the $21^{\text {st }}$ century exhibit much more complex behaviour.

Megacities have their roots - their First Occurrence Datum, or 'FAD' as geologists express it in discussing chronostratigraphic units, in $19^{\text {th }}$ century London, which grew to a population of over 3 million in 1850, and over 7 million in 1910. Megacities have produced a fossil record of complex burrow systems at and below ground level. These burrow systems, as well as being more extensive and complex than those produced earlier in human history, are orders of magnitude larger and more complex than any non-human burrow systems; they represent in effect a new phenomenon in geology, one that is driven by conscious thought and by mechanisation. They include the trace fossils of: locomotion by people (e.g., Metros, canals, surface and subterranean (i.e., tunnels) walkways, roads and train lines), power (conduits for electrical cables and gas and steam lines) and ideas (telecommunications links); faecal traces (sewers and buried rubbish dumps), dwelling structures (underground buildings and foundations); resting traces (underground car parks) and even feeding traces (if quarries and mines, or the basements or foundations of fast food restaurants are considered).

A useful datum for defining the origins of this behavioural and community complexity might be to designate underground metros as a particular style of human trace fossil associated with the mass movement of people, and take the world's first underground line - the Metropolitan Line of London (construction began 1861, see Figs 2, 3), as the GSSP (Wolmar 2005). One of the several original metro stations, including Baker Street (1863) and Euston Square (1863), might be selected as the 
locus for a Golden Spike that would physically define a GSSP for a stage of human development or even the base of the Anthropocene.

The building and maintenance of megacities (and the survival of their human inhabitants) has been responsible, directly or indirectly, for many of the other geological changes associated with the Anthropocene, such as $\mathrm{CO}_{2}$ emissions, changed patterns of erosion and sedimentation, and biodiversity loss. Megacities have now developed in Europe (e.g. Moscow, London, Paris), Asia (e.g. Shanghai, Beijing, Tokyo, Seoul, Mumbai), Africa (Cairo, Lagos), and the Americas (e.g. Mexico City, New York City, Sao Paulo), with 27 metropolitan centres exceeding 10 million inhabitants (Brinkhoff 2012). Their spread has been effectively instantaneous from a geological perspective, and the accelerating growth of megacities in the latter part of the $20^{\text {th }}$ century has covered, in particular, large areas of subsiding coastal plains and river deltas (e.g. Shanghai, see Zalasiewicz et al. this volume a) where their preservation potential is high. Their physical record is a good proxy for the Great Acceleration of the industrial revolution (Steffen et al. 2007, 2011). As one of the most extensive, durable and geologically distinctive aspects of the Anthropocene, megacities have a strong claim to become a significant part of any proposed formal definition.

The evolution of urban areas was diachronous, taking several thousand years to become the preferred habit of Homo sapiens. In 1800 only $3 \%$ of the global population lived in cities, but by 2008 more than $50 \%$ of the global population was living in cities (UNFPA 2007), which cover about $3 \%$ of the Earth's land surface (GRUMP 2005). Of this population about 7\% live in the megacities (GRUMP 2005). Cities, and specifically megacities, account for a comparatively small percentage of the global distribution of environments. 
However, as seen with the definition of the Cambrian, the indicator trace fossil event is also likely to be diachronous and representative of a particular set of environmental parameters. These do not represent suitable arguments against using the development of large-scale trace fossils in the evolution of megacities as an indicator for the start of the Anthropocene. This definition is comparable to that used to define the base of the Cambrian-in which a significant biological-environmental signature was recognized and then an event defined, which is the lowest occurrence of a trace fossil, to specify the base of a chronostratigraphic unit. Evidence from historical records, the introduction of novel minerals (Zalasiewicz et al. this volume b) or artefacts (Ford et al. this volume) make dating of the Anthropocene interval possible to an annual or decadal accuracy, which is five or six orders of magnitude more precise than currently possible for the base of the Cambrian.

We wish to thank the two anonymous referees for their constructive reviews of this paper. CNW publishes with the permission of the Executive Director, British Geological Survey.

\section{References}

Brasier, M., COWIE, J.W. \& TAYLOR, M. 1994. Decision on the PrecambrianCambrian boundary stratotype. Episodes, 17, 95-100.

Brasier, M.D., ANtCliffe, J.B., \& CALlow, R. 2011. Evolutionary trends in remarkable preservation across the Ediacaran-Cambrian transition and the impact of metazoan mixing. pp. 519-567 in Allison, P. \& Bottger, D.J. (eds) Taphonomy and Bias through Time,. Springer Verlag, Dordrecht. 
BRINKHOFF, T. 2012. The Principal Agglomerations of the World. http://www.citypopulation.de/cities.html

DornBos, S.Q., BOtTJER, D.J. \& CHEN, J-Y. 2005. Paleoecology of benthic metazoans in the Early Cambrian Maotianshan Shale biota and the Middle Cambrian Burgess Shale biota: evidence for the Cambrian substrate revolution. Palaeogeography Palaeoclimatology Palaeoecology, 220, 47-67.

FedonkIN, M.A. \& WAggoner, B.M. 1997. The Late Precambrian fossil Kimberella is a mollusc-like bilaterian organism. Nature, 388, 868-871.

Ford, J.R., Price, S.J., CoOPER, A.H. \& WATERS, C.N. An assessment of lithostratigraphy for anthropogenic deposits. In: A Stratigraphical Basis for the Anthropocene.

Gehling, J., Jensen, S., Droser, M.L., Myrow, P.M. \& Narbonne, G.M. 2001. Burrowing below the basal Cambrian GSSP, Fortune Head, Newfoundland. Geological Magazine, 132, 213-218.

GRUMP (Global RuRal Urban Mapping Project). 2005. The Growing Urbanization of the World. http://www.earthinstitute.columbia.edu/news/2005/story03-0705.html

JENSEN, S. 2003. The Proterozoic and earliest Phanerozoic trace fossil record: patterns, problems and perspectives. Interrogative and Comparative Biology, 43, 219-228.

LANDING, E. 1994. Precambrian-Cambrian global stratotype ratified and a new perspective of Cambrian time. Geology, 22, 179-182.

LANDING, E. \& WESTROP, S.R. 2004. Environmental patterns in the origin and evolution and diversification loci of Early Cambrian skeletalized Metazoa: evidence from the Avalon microcontinent. pp. 93-105 in Lipps, J.H. \& Wagoner, 
B. (eds) Neoproterozoic-Cambrian Biological Revolutions. Paleontological Society Papers, 10.

LANDING, E., PENG, S.C., BABCOCK, L.E. \& MoczYDŁOWSKA-VIDAL, M. 2007. Global standard names for the lowermost Cambrian series and stage. Episodes, 30, 283-289.

MACNAUGHTON, R.B. 2007. The application of trace fossils to biostratigraphy. pp. 135-148 in Miller, W III (ed.). Trace fossils: concepts, problem, prospects. Elsevier..

MARShall, C.R. 1990. Confidence intervals on stratigraphic ranges. Paleobiology, $16,1-10$.

Martin, M.W., Grazhdankin, D.V., Bowring, S.A., Evans, D.A.D., Fedonkin, M.A. \& KIRSCHVINK, J.L. 2000. Age of Neoproterozoic bilaterian body and trace fossils, White Sea, Russia: implications for metazoan evolution. Science, 288, 841-845. Peng, S., BABCock, L.E. \& CoOPeR, R.A. 2012. The Cambrian Period. pp. 437-488 in Gradstein, F.M., Ogg, J.G., Schmitz, M. \& Ogg, G. (eds) The Geologic Time Scale: 2012 (Volume 2). Elsevier B.V. ISBN: 978-0-44-459434-1.

Steffen, W., Crutzen, P.J. \& McNeill, J. 2007. The Anthropocene: Are Humans Now Overwhelming the Great Forces of Nature? Ambio, 36, 614-621. Steffen, W.Å.P., Deutsch, L., Zalasiewicz, J., Williams, M., Richardson, K., Crumley, C., Crutzen, P., Folke, C., Gordon, L., Molina, M., Ramanathan, V., Rockström, J., SchefFer, M., SchellnhubeR, J. \& SVEdin, U. 2011. The Anthropocene: from global change to planetary stewardship. Ambio, 40, 739-761. Vannier, J., Calandra, I., Gaillard, C. \& ŻylińSkA, A. 2010. Priapulid worms:

Pioneer horizontal burrowers at the Precambrian-Cambrian boundary. Geology, 38, 711-714, doi:10.1130/G30829.1 
WOLMAR, C. 2005. The Subterranean Railway: How the London Underground was built and how it changed the city forever. Atlantic Books. ISBN 1-84354-023-1.

Wood, R.A., GrotZinger, J.P. \& Dickson, J.A.D. 2002. Proterozoic Modular Biomineralized Metazoan from the Nama Group, Namibia. Science, 296, 23832386. [DOI:10.1126/science.1071599]

UNFPA (United Nations Population Fund). 2007. State of World Population 2007: Unleashing the potential of Urban Growth. 108 pp.

YUAN, X., Chen Z., XIAO, S., ZHOU, C. \& HUA, H. 2011. An early Ediacaran assemblage of macroscopic and morphologically differentiated eukaryotes. Nature, 470, 390-393.

ZalASIEWICZ, J.A., Williams, M. \& WATERS, C.N. this volume a. Can an Anthropocene Series be defined and recognised? In: A Stratigraphical Basis for the Anthropocene.

ZALASIEWICZ, J.A., KRYZA, R. \& WiLLIAMS, M. this volume b. The mineral signature of the Anthropocene in its deep-time context. In: A Stratigraphical Basis for the Anthropocene.

Zhuravlev, A.Yu., Liñan, E., Gámez Vintaned, J.A., Debrenne, F. \& Fedorov, A.B. 2012. New finds of skeletal fossils in the terminal Neoproterozoic of the Siberian Platform and Spain. Acta Palaeontologica Polonica, 57, 205-224. 


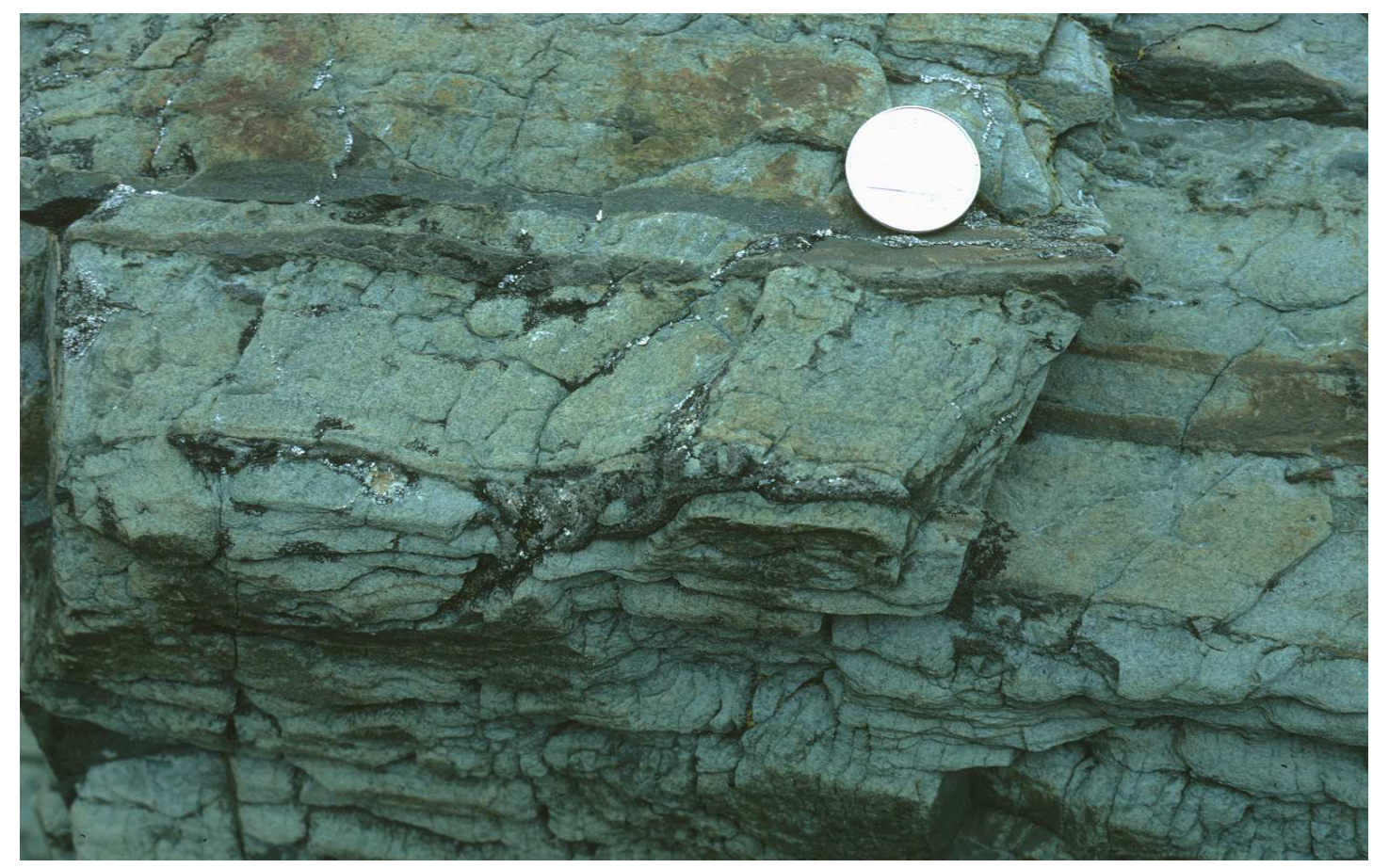

Figure 1. Specimen of the ichnofossil Treptichnus pedum (Seilacher) showing branches and galleries of this shallow burrow (arrow points to trace fossil). Specimen located precisely at Global Stratigraphic Section and Point (GSSP) selected for the base of the Cambrian System (as well as the Terreneuvian Series and Fortunian Stage; see Landing, 1994). The sediment-filled specimen of $T$. pedum is weathered out of very fine-grained sandstone of lower Chapel Island Formation at Fortune North section, just west of Fortune village, southeastern Newfoundland. 


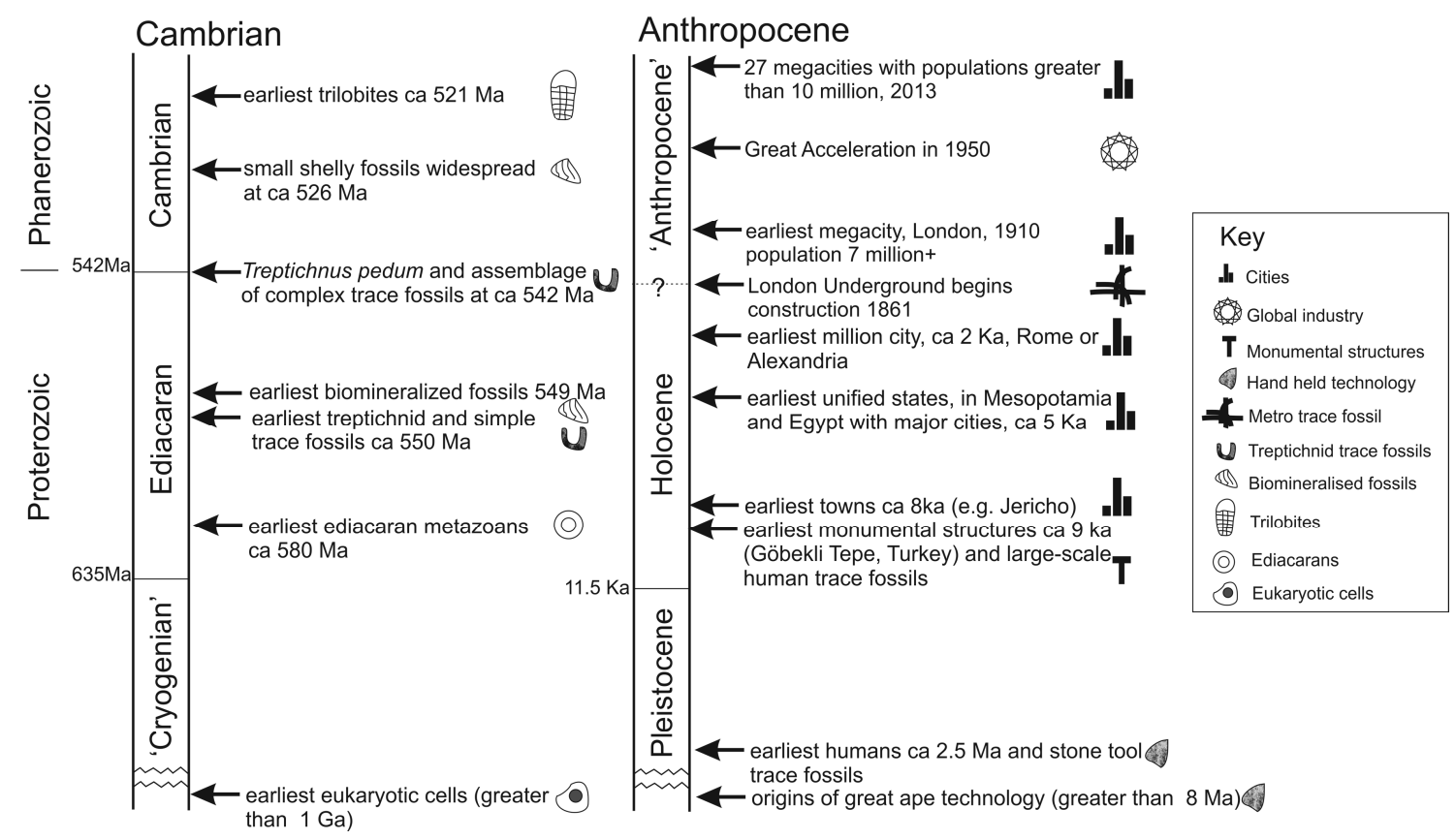

Figure 2. Biotic events associated with the Proterozoic-Phanerozoic boundary compared with the human events of the past 3 million years. The traditional base of the Cambrian System was early regarded as lying at the lowest appearance of trilobites. The widespread occurrence of small shelly fossils that identify the Siberian 'Tommotian Stage' was also once mooted as the boundary. The boundary approximates the lowest occurrence of the assemblage of trace fossils of the basal Cambrian Treptichnus pedum Biozone. The late Proterozoic is also associated with the global appearance of metazoans (the Ediacaran Period), early trace fossils, and very low diversity mineralised taxa such as sponges with their spicules, tubular fossils (earliest Anabarites), and calcareous problematica limited to the Ediacaran (Cloudina, Namacalanthus) - these evolutionary signatures may be seen as heralding the significant animal behaviour innovations of the earliest Cambrian. The record of events leading to the development of the complex trace fossils of megacities is similarly complex, finding its roots in the technology of great apes, through the stone tools of early humans, to the monumental structures of the past 
9,000 years, culminating in the megacities. Each step can be seen as a staging post to the main event, in this case taken as the trace fossil systems of the megacities.

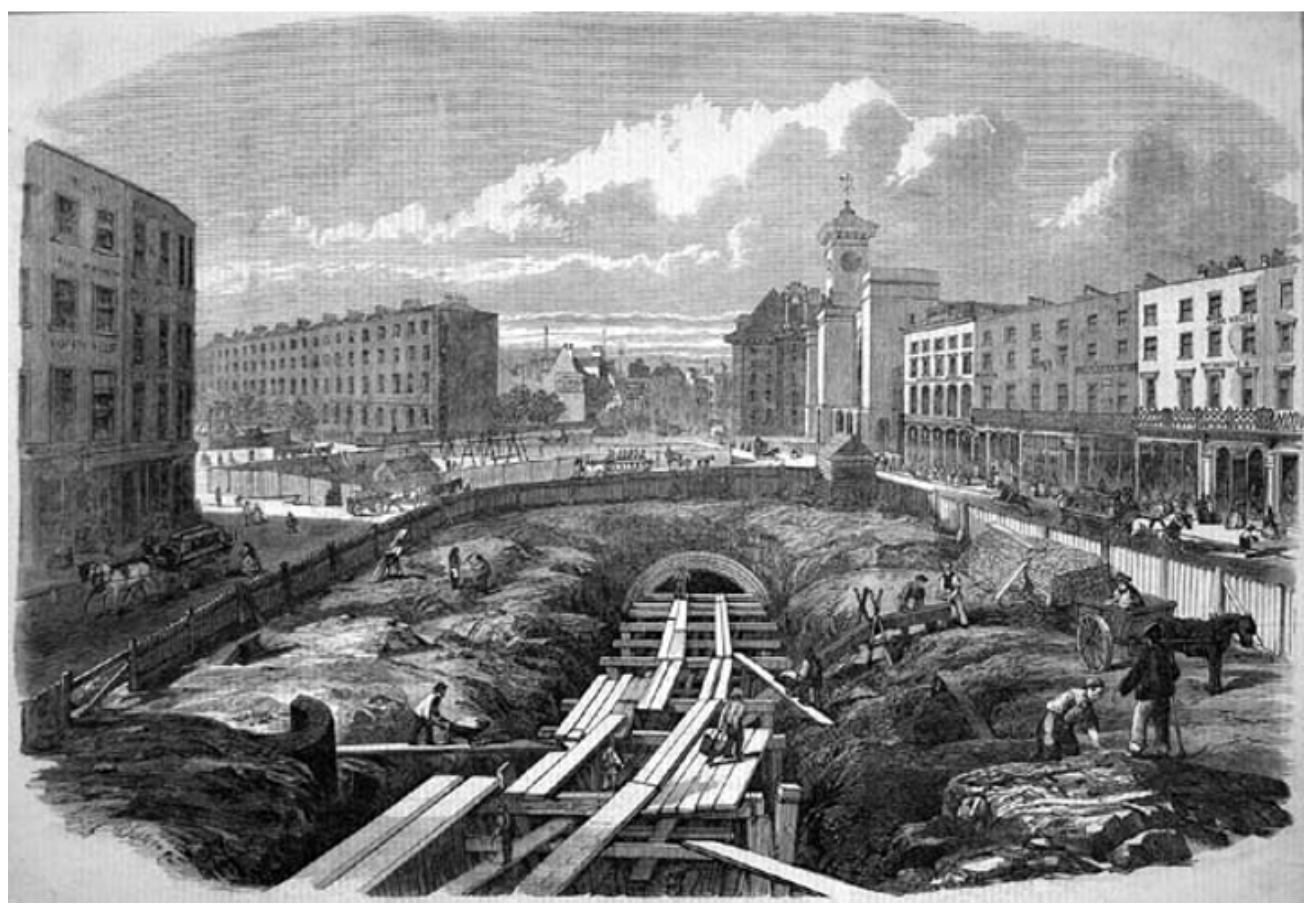

Figure 3. Construction of the world's first underground railway, the Metropolitan Line in London, 1861. Image freely available from Wikicommons at:

http://en.wikipedia.org/wiki/File:Constructing_the_Metropolitan_Railway.png 